\title{
Understanding the moral economy of post-Soviet societies: an investigation into moral sentiments and material interests in Kyrgyzstan
}

\author{
Balihar Sanghera, Aibek Ilyasov, and Elmira Satybaldieva
}

In a recent issue of the International Social Science Journal on moralising capitalism (2005), the contributors argued that moral norms, rules and values can produce good economic outcomes through the principle of non-domination in market institutions, decentralised processes of democratic decision-making, social self-esteem, human rights, justice, the rule of law and corporate ethics. While we are sympathetic to their agenda, we are critical of their ideas for two reasons. First, in examining the moral fabric of the economy, several contributors unwittingly reduced economic practices to capitalist structures, and sometimes to market exchanges. It is undoubtedly true that multinationals and markets are significant economic institutions in modern industrialised societies, but nevertheless we take a broader meaning of the economy to refer to the production and reproduction of goods and material things to sustain life, so that the public sector and the household are equally important economic institutions. Feminists have long criticised mainstream economists for neglecting the productive nature of housework

Balihar Sanghera is a lecturer in sociology at the School of Social Policy, Sociology and Social Research, University of Kent, UK. His current research is on the moral and ethical aspects of political economy. He is a joint editor, with Sarah Amsler and Tatiana Yarkova, of Theorizing social change in post-Soviet societies (Peter Lang, forthcoming).

Email: b.s.sanghera@kent.ac.uk

Aibek Ilyasov is a researcher at the SIAR research company in Bishkek, Kyrgyzstan. His current research is critical theory. He has written several reports on ecological conventions and parliamentary elections in Kyrgyzstan.

Email: aibek_ss@yahoo.com

Elmira Satybaldieva is a lecturer in journalism at the Department of Journalism, American University, Central Asia, Bishkek, Kyrgyzstan. Her current research is on clan politics in Kyrgyzstan. She has written several reports on child poverty and the mass media in Kyrgyzstan.

Email:seak8@yahoo.com
(Folbre 1994). Second, in discussing economic morality, several contributors treat ethics as an external set of rules, procedures and conventions important in shaping economic practices in the public sector, social networks and markets. ${ }^{1} \mathrm{We}$ aim to contribute to the literature on post-Soviet 
transitions by emphasising that moral sentiments are vital elements in the dynamics of social change. This article crosses disciplinary boundaries by engaging with the literature on postcommunism, political economy and moral philosophy to analyse the post-Soviet moral economy. ${ }^{2}$ More broadly, we aim to critique the literature on political economy, which tends to neglect the significance of moral emotions in everyday economic practices.

Since its independence from the Soviet Union in 1991, Kyrgyzstan has undertaken major economic reforms, such as large-scale privatisation, deregulation of the public sector, trade liberalisation and labour market reforms (Green and Bauer 1998). In many ways the economic strategy of shock therapy has imposed a new liberal ethos onto decades of Soviet practices to shape the social and economic conditions in Kyrgyzstan. While human agents inhabit their social and cultural structures involuntarily, they are nevertheless evaluative and reflexive beings, pursuing the concerns, commitments and life projects that are significant to their well-being, and they circumvent, repudiate, resist and transform social constraints and enablement to achieve the goals they find important (Archer 2003, pp. 135-148). Far from being trivial or banal, human emotions possess cognitive qualities, relate to objective conditions, have real effects on behaviour and motivate us to nurture our responsibilities and care for others and to protect our own sense of social worth (Nussbaum 2001, pp. 24-33; Sayer 2005, pp. 55-59). This article shows how the emergent post-Soviet economic structures, opportunities and resources, such as class structure, social inequalities, market incentives and organisational rules, have negatively affected human emotions, leading to a lack of compassion, integrity, stigma and discrimination.

There are several accounts of the moral economy that draw on different theoretical traditions, from classic liberalism and neoMarxism to neo-Aristotelian (for a general discussion see Booth 1994; O’Neill 1998; Sayer 2004; Sen 1999). The aim of this article is not to offer a comprehensive literature review on the moral economy, but to examine key perspectives on post-Soviet societies that emphasise moral and ethical aspects. We discuss three competing conceptual approaches: the economic market, the socially embedded approach and the moral sentiments approach. The first two perspectives are common in political economy, and the third is located more often in moral philosophy. We argue for a moral sentiments approach to the post-Soviet moral economy that combines several elements: ethical care and commitments, moral sentiments and character and intrinsic and instrumental values (Archer 2000, pp. 197-220; Fevre 2003, pp. 21-25; MacIntyre 1985, pp. 187197; Nussbaum 2001, pp. 24-33; Sayer 2005, pp. 111-121; Sen 1999, pp. 36-40; Smith 1976, pp. 9-13, 109-117 [1790]). This approach offers a conception of human beings as interdependent and vulnerable beings who care for and care about others, and rejects the traditional view of individuals as rational and independent beings subject to self-regarding concerns (Groenhout 2004, pp. 23-40; van Staveren 2001, pp. 6-24).

The article is divided into four sections. In the first section, we discuss and evaluate three approaches to the post-Soviet moral economy. The next section gives some general information about Kyrgyzstan and outlines the research design of the project. The third section examines the nature of the public sector, social networks and real markets in Kyrgyzstan. Finally, we make some concluding remarks.

\section{Conceptualising morality in the economy}

In comparing the different approaches to understanding how ethical relationships and economic practices intertwine in post-Soviet transition societies, we state their key ideas and their implications for good practices. The three approaches to the post-Soviet moral economy are:

1. the economic market approach, which stresses the private and civilised aspects of market exchanges;

2. the socially embedded approach, which emphasises collective values, rights and entitlements

3. the moral sentiments approach, which focuses on moral emotions, character and recognition.

\section{The economic market approach}

The early classical writers on political economy recognised the moral ambiguity of capitalism as societies came to develop complex social 
divisions of labour in a highly competitive environment (Hirschman 1982; O'Neill 1998). On the one hand, individuals are free from feudal-like bondage and hierarchical societal relationships. In the marketplace individuals are all formally equal and free and they develop a capacity for making personal judgements and for being responsible for their own actions (Booth 1994). Indeed, liberals argue that trade and commerce can strengthen the moral attitudes of a society as competitive market forces tame individuals' passions and individuals learn to honour contracts, respect justice and obey the law for fear of losing their reputation as trustworthy economic actors. As Simmel (1955, pp. 61-64) notes, in competitive markets the loss of income and sales to rivals can civilise unsocial and dishonest behaviour. Moreover, economic agents learn to cooperate, reciprocate and take responsibility for themselves; otherwise trust fragments, leading to the collapse of economic development. ${ }^{3}$

On the other hand, Smith (1976, pp. 61-66 [1790]) and Veblen (1918, Ch. 4) recognise that wealth can undermine integrity, worthiness, judgement and duties. For example, some consumption goods can be valued because they are conspicuous items and thus demonstrate economic affluence rather than being enjoyed for their intrinsic pleasures. Moreover, in a fiercely competitive environment, individuals may act opportunistically and break promises and contracts for their immediate profit (Williamson 1975). As Smith (1974 [1776], p. 232) also notes, professions can conspire together to act against the public interest to further their own material interest.

The economic market approach to morality in transition economies focuses on how individual actions are mediated through the market system, acknowledging the latter's liberating and civilising effects as well as its corrosive and destructive effects (Kaneff 2002; Liu 2003; Nee 1989; Poznanski 2000; Szelenyi and Kostello 1996). As Nee (1989) implies, this approach suggests that as prices communicate important information about economic costs and gains and individuals are deemed to know what serves their own interest, the state, as far as possible, must establish markets and property rights to allow individuals the freedom to exchange goods and services. Extensive use of markets and private property rights can generate efficient and equitable outcomes (except in cases of market failure, among others).

According to this approach, good practice is when individuals pursue their own selfinterest, and, independently of others, rationally weigh up the costs and benefits of their action (Holton 1992, pp. 54-67). As there are real opportunity costs to acting ethically, economic actors have to calculate their utility by weighing up the gains and losses. Their subjective desires and preferences define their projects and goals and they are moved to maximise their private happiness. For instance, it can be argued that sometimes in Kyrgyzstan a traffic police officer will stop cars in the hope of extracting bribes from drivers because it pays to do so. The officer, who receives poor wages, is unlikely to be caught since the monitoring and disciplinary procedures are weak. Of course, unintended consequences (such as letting off bad drivers and a subsequent increase in road accidents) may occur if officers act only to promote their own personal gain and fail to enforce proper and safe driving.

\section{The socially embedded approach}

Various writers, such as Polanyi (2001) and Thompson (1971), argue that non-contractual elements such as tacit knowledge, institutions, rules, norms and customs shape economic rationality and constrain self-interest. As Polanyi (2001) notes, contrary to formal economics, economic practices are socially embedded and the economy is a process involving both market and non-market relationships and economic and non-economic values. In contrast to the individualistic framework of the first perspective, this approach argues that vested interests, collective entities and the state vie for power and influence to construct social conventions, policies and agreements. The market society is conflictridden and dominated by inequality, exploitation and injustice.

There is an inherent tension in the socially embedded economy. On the one hand, the economy must be adequately embedded to ensure effective communication, trust and coordination (Granovetter 1985). For instance, a market economy can experience an economic crisis if there is insufficient stability and inadequate time for capital to realise its surplus value. 
Non-market institutions (such as the welfare state and professional associations) and social networks (such as kinships and clans) provide necessary conditions for successful reproduction and transformation of capital (O'Neill 1998, pp. 98-99). These institutions and networks ensure formal and informal safeguards to capital accumulation; otherwise there is too little embedding, causing excessive labour exploitation, consumer deception and fragmented ties to endanger capital accumulation in the long run.

On the other hand, the market must disembed social relationships, liberate economic commitments from ossified obligations and social habits and forge new social relationships (Sayer 1995, pp. 88-90). Market competition rewards successful economic creativity, innovation and enterprise, at the same time as it undermines traditional rights, historical entitlements and social norms. Without economic competition, organisations, firms and communities stagnate and decline. Economic progress and social justice are in tension at moments such as when plant is relocated and organisations are reformed. The capitalist welfare state, civic institutions, professional associations and social groups need to carefully regulate the causes and consequences of market forces without excessively embedding the circuit of capital (Offe 1984, pp. 48-57).

The socially embedded approach to a postSoviet moral economy examines how social and political changes to civil rights, welfare entitlements and social conventions have transformed the social economy through privatisation programmes, deregulating the private sector, liberalising trade, labour and property laws and marketisingthe public sector (Burawoy and Verdery 1999; Hann 2003; Kopstein 2001; Mandel and Humphrey 2002; Offe 1996; Verdery 1996). This approach is critical of the neo-liberal restructuring of post-Soviet societies, pointing out how emergent market structures, rules and rights have weakened and constrained the wellbeing of poor households, women and minority groups (Attwood 1997; Kuehnast and Dudwick 2002; Nazpary 2002). Nevertheless, social embeddedness is always contingent, as individuals seek to compete with each other and try to improve their social rights and entitlements.

According to this approach, good practices follow rules, codes of practice, social norms and duties (see Durkheim 1957, pp. 1-41 on professions). Furthermore, institutional safeguards are in place to prevent social spheres, such as education and medicine, being dominated and organised according to market principles (Walzer 1983, pp. 6-13). As Etzioni (1988, pp. 11-13) notes, to live well is to know ones duty and to respect social conventions. This does not mean that individuals become oversocialised to norms and rules so that they are unable to reflect upon their situation, but that their behaviour must remain rule-bound. Moral disorder occurs when: a) individuals fail to adhere to the rules of the game, and behave egoistically; and b) social goods become dominated by the market, and turned into commodities for money exchange.

\section{The moral sentiments approach}

The moral sentiments approach conceives of individuals as deliberative and reflexive human beings, who pursue ultimate concerns, have ethical commitments and are guided by moral sentiments (Archer 2000, pp. 197-220; Sayer 2004). Nussbaum (2001, pp. 33-33) argues that emotions have real effects on behaviour and relate to things that we have reason to value. Emotions can trigger deliberate intervention and purposeful behaviour in situations where individuals are in need, or have faced misfortunate and deserve care. Moral emotions are as important as economic resources and human rights for human well-being, since emotions can respond to individuals in vulnerable situations and can inform and motivate social actors to give assistance, care and support in ways that markets and the state cannot.

Adam Smith (1976 [1790]) is careful to note that moral behaviour can be motivated by different emotions: positive emotions (generosity, benevolence and honesty), negative emotions (disgust, anger and shame) and selfish emotions (self-love and self-deceit) ${ }^{4}$ (see Griswold 1999). Disgust, pride and shame can move individuals to withdraw from social situations that threaten their sense of well-being. For example, individuals can become ashamed or angry when their dignity has been undermined and, to avoid further stigma and humiliation, may withdraw from the social relationships that make them feel uncomfortable. Sometimes emotions can have negative consequences. Citing 
Smith, Sen (1999, p. 71) argues that poor people who feel ashamed about appearing in public, are inhibited in participating in the community.

Immoral practices, meaning those which harm human well-being, can also occur. Following the human capabilities approach (Nussbaum 2000; Sen 1999), human well-being is damaged when people lack real opportunities and positive freedoms (i.e., capabilities) to achieve their concerns and goals, and when their ability to realise similar goals is unfairly allocated. This approach to ethics is closely linked to human rights discourse, but places more emphasis on whether people really possess the power to achieve their goals. Although social and political rights may exist in a country, these rights may be difficult to put into practice because of existing social inequalities (Nussbaum 2000). One implication of this understanding of human wellbeing is that we can develop a list of crosscultural norms of core capabilities that can act as a minimum threshold of human well-being. A possible list could include being able to be healthy, being able to have free speech and being able to engage in various forms of social interaction.

There are two major impediments to moral behaviour. First, as Nussbaum (2004, p. 174) notes, individuals can respond to situations of tragedy and misfortune with negative emotions such as disgust and envy. Often, a lack of compassion betrays discrimination on the basis of social class, position and identity. Sayer (2005, pp. 163-167) notes that middle-class individuals tend to feel contemptuous and condescending towards working-class individuals, who tend to feel humiliated and stigmatised by and envious of those with better material and cultural lifestyles.

Second, Smith notes how particular institutions can harm us. Economic institutions such as state monopolies and trade associations can encourage selfish passions and work against the public interest (1974, pp. 164, 232 [1776]). Social institutions (such as established religion) can cause both excessive and weak passions such as religious fanaticism and a lack of tolerance. Furthermore, organisational procedures, institutional rules and economic targets can influence individuals to pursue external goals to the point of sacrificing ethical commitments and the quality of their work (Keat 2000, pp. 81-85, 86-91).
Thus, surgeons in public hospitals may limit the time they give to examinations and post-operation care so as to treat more patients, to satisfy government targets and to reduce waiting time.

An important feature of the moral sentiments approach is that while individuals are motivated to achieve their ultimate concerns and ethical commitments, they also want social status, income and power and are governed by rules and economic targets (Sayer 2005, pp. 111 117; Keat 2000, pp. 22-28, 111-115; Mason 1996, pp. 201-206). However, status, income, power and rules are seen as conditioning the way individuals engage with their ultimate concerns and commitments, rather than being their ideals and aspirations (see also Oakley and Cocking 2001, pp. 85-88). Smith (1976 [1790]) also argues that moral rules can be necessary to counter the tendency to moral corruption (self-deceit and self-love). Rules act to guide our actions and to enable us to reflect on our behaviour in particular situations (Griswold 1999, p. 187). While rules such as "always treat others with equal respect" can help us to focus on what matters ethically in particular circumstances, we cannot make use of them without an understanding of the context, and this requires and guides emotions, imagination and a feel for the relevant particulars (Griswold 1999, pp. 190-192). ${ }^{5}$

According to the moral sentiments approach, markets, organisations and communities are always a site of moral assessments and implicit ethical commitments. As individuals mediate incommensurable values, they must employ practical reasoning to balance different commitments, emotions and demands: such as balancing integrity, honesty, praiseworthiness and excellent practice with status, power, praise and efficiency (Sayer 2003; van Staveren 2001). For instance, if Kyrgyzstani lecturers are mindful only of their income, promotion and reputation, then scholarly knowledge, learning and critical thinking may suffer. Nonetheless, good academics require a certain level of praise and income; to claim the contrary would be deceitful.

\section{An evaluation of the three approaches}

We offer several reasons for accepting the moral sentiments approach. As the economic market approach predominantly sees moral behaviour 
as a private exchange of utility, it does not adequately conceptualise practices and relationships in professional, family and community settings, where integrity, honesty, compassion and trust are not easily achievable, social activities have incommensurable values, and social encounters produce moral sentiments that affect conduct (Smith [1790] 1976, pp. 9-13). Social activities such as scientific work often involve making deep commitments, obtaining recognition from significant others and doing worthwhile acts, and they cannot be reduced to maximising happiness or profits (O’Neill 1998, pp. 151-154).

The socially embedded approach seems to have some plausibility in post-Soviet countries, but its focus on rules, conventions and duties tends to neglect the importance of reflexivity and deliberation. While rules, conventions and traditions may instruct individual action in general and simple circumstances, they lack sensitivity and are too abstract and vague for complex and highly specific everyday encounters.

The moral sentiments approach possesses two distinct advantages (Sayer 2003, 2004). First, emotions and reason fuse to motivate individuals to act ethically. The motivation to act well is as important as knowing how to act. Where values and beliefs are shaped by an external authority or a set of social norms and rules, practices and relationships can become alienating and cynical (Sayer 2005, pp. 8-9). Second, moral emotions, reflexivity and sensitivity to particulars enable individuals to make moral judgements of their local contexts in ways that mediate between ethical concerns and goals and economic rewards and interests. In novel and complex situations, moral sentiments and character motivate and guide individuals to act well.

\section{Background information and research design}

Since the early 1990s Kyrgyzstan has been less authoritarian than its central Asian neighbours (Anderson 1999). It was one of the first countries in the region to introduce pro-market reforms and became a member of the World Trade Organisation in 1998. Notwithstanding the greater economic and political openness in Kyrgyzstan today, the Kyrgyzstani political regime has always adopted measures from the Soviet era to control civil society. Furthermore, political authoritarianism and clan loyalties have exacerbated social divisions: powerful clans and elite groups own lucrative business assets and occupy top government posts. In March 2005 a popular revolt, the so-called Tulip Revolution, sparked by widespread allegations of government interference in parliamentary elections and fuelled by poverty and corruption, overthrew Askar Akayev, the President, who had been in power since independence.

Kyrgyzstan is one of the poorest and most unequal post-communist countries. There are 47.6 per cent of the people who live below the poverty line, 13.5 per cent live in conditions of extreme poverty and the share of total income earned by the poorest 20 per cent of the population is 7.6 per cent (UNDP 2002; World Resources Institute 2006). The unemployment rate is about 18 per cent, though in rural areas it is much higher. In many poor households one or more members migrate to the capital or overseas to find better paid jobs and support the family by sending money home. There are officially 320,000 Kyrgyzstani migrants in Russia alone, constituting about 6 per cent of the population.

For our study we conducted semistructured interviews with 33 participants from a broad spectrum of occupations who possessed some experience of the Soviet planned economy, and asked them questions on their views of the transition to a market economy. The participants were chosen to cover different age groups, ethnicities and genders, and the following were interviewed: two doctors, three police officers, two sex-workers, two lecturers, two lawyers, a school teacher, an accountant, an office worker, a factory cleaner, two NGO officers, a farmer, a sales assistant, two housewives, a café worker, two sports trainers, two journalists, three businesspeople, a civil servant, a UN coordinator and two taxi drivers. Furthermore, one of the authors worked in universities in Novosibirsk in Russia and Bishkek in Kyrgyzstan for four years and the authors have had several years of opportunity to observe the social life of the region.

The interviews were conducted in Russian. All the interviews were tape-recorded, and the participants were reassured about confidentiality and anonymity. On average, each interview lasted for 45 minutes. The participants were 


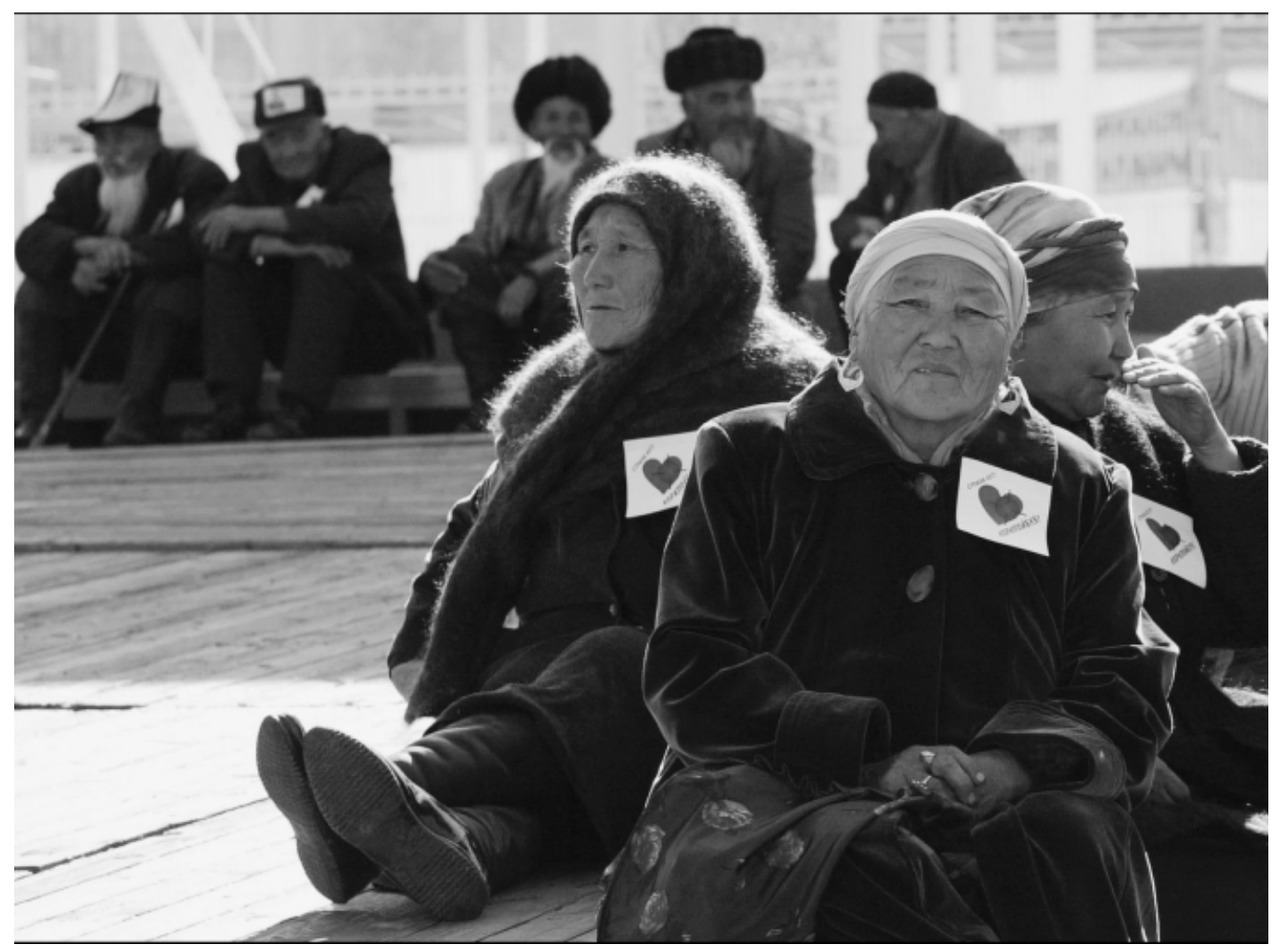

Supporters of the Kyrgyz Prime Minister at a rally in Bishkek, Kyrgystan, October 2005. Vyacheslav Oseledko/AFP

either paid or given a gift for giving up their time for the interview. The interviews were transcribed and then translated into English. Subsequent analysis was based on the use of Atlas.Ti, a computer software programme for analysing qualitative data.

\section{The public sector, social networks and markets}

This section examines how ultimate concerns, commitments and integrity are sometimes in tension and conflict with economic rewards, targets and external goals in the public sector, social networks and real markets, and how participants use moral sentiments and moral rules to try to mediate between these different values.

\section{The public sector}

As the public sector receives fewer state subsidies and engages in cost-cutting, our interviewees in different occupations describe how they have come to value economic rewards at the expense of their ethical commitments and professional goals. On the face of it their lack of professional commitment can be condemned as moral corruption, but in fact the interviewees reveal that they have a complex set of competing ethical commitments. Natalya, ${ }^{6}$ a police officer, suggests that the corruption in her profession is morally acceptable in order to provide for her family:

Natalya: The militia work mostly for money now. Offenders may pay the militia and be released. It works very well. You can bribe anyone. There are very few honest people. I wish these people would think about the area of their activities and their obligations. The militia should 
protect people from offenders, and not promote an increase in their number.

Interviewer: Why do you think those who work in the militia changed?

Natalya: They have their own families that they need to feed. That's why they take bribes. Maybe, if their salary were bigger, they would be taking fewer bribes.

As in most cases, public sector workers and professionals justify corruption as being necessary for household survival. Their sense of living and being, their modus vivendi, rests upon family commitments, rather than upon a fragile professional ethos. In prioritising their ultimate concerns, they place the family first, and at times professionalism is incompatible with adequately meeting family responsibilities. Given the multiplicity of concerns, ethical evaluation defies straightforward judgements of condemnation or praise when assessing the ethical (mis-)conduct of public sector workers and professionals. Since social relationships are intertwined, many Kyrgyzstanis have discovered how, in trying to pursue one dominant concern, unintended negative consequences for other concerns emerge. Olivier de Sardan (1999) notes that in developing countries corruption is complex, in part because social practices are deeply embedded, so that it is difficult to isolate, abstract and evaluate a single practice from the rest.

Higher education has also become a site of struggle for balancing professional concerns and economic rewards, as lecturers try to maintain their professionalism in conditions of low pay, inadequate teaching resources and poor infrastructure. Lecturers earn on average US\$40 a month for a normal teaching workload, but this is insufficient as a primary source of income for a family, since an urban family needs at least US\$100, and a rural one US\$60 to meet basic costs. One survival strategy for lecturers is to demand bribes or gifts from students for high grades. A student poll backed by Kyrgyzstan's ombudsman found that out of the 520 students polled, 54 per cent admitted to having given lecturers sweeteners to ensure that they received good marks (The Times Higher Educational Supplement 2006). According to the poll, most academics preferred cash, though 5 per cent of students said some lecturers required them to carry out household chores, 3 per cent said the lecturers preferred to be entertained at expensive restaurants, cafes and saunas, and 3 per cent said some lecturers demanded sex from them. Asel, a non-governmental organisation director, describes the tariff rates for different grades:

There are a number of students who, without attending any examination sessions get their grades for a set price. Recently student volunteers in our organisation told me that it costs 1,500 soms [about US\$38] to pass exams with grade 5 [excellent], 1,000 soms for grade 4 [good], 500 soms for grade 3 [satisfactory] at [a local] university. You don't even have to study, you just pay the bill and get the grades, so how can we discuss quality at all? On the other hand, I know that these graduates will obtain good jobs as the system of family relations is well developed and efficient.

Asel is also angry because the marketisation of higher education gives an unfair advantage to students from affluent backgrounds who are in a better position to pay the lecturers and can use their social connections to get a well-paid job. The integrity of higher education has been undermined as lecturers seek to make ends meet both by working longer hours and cultivating a culture of bribery.

What appalls many of our interviewees is the lack of sympathy, care and compassion of public sector workers and professionals. Their disgust and anger target doctors and nurses in particular. Natalya, a police officer, and Dima, an office worker, are both shocked at how the medical staff disregard the well-being of their patients:

Natalya: Once my father was taken to the hospital and his ward-mate could not pay for his medications. He had no relatives who could help him. He was abandoned there. Not a single nurse would help him until we called her a few times. We had to call the nurses all the time to tell them to feed the guy and give him medication, for he was virtually dying. This happens everywhere, and even in cancer hospitals. If a person has money to pay for medications, they will get them. If they are poor, they won't get any.

Dima: Doctors should remember their Hippocratic Oath, so it's not like if you pay - we take care of you, if you don't pay- you can die, we don't care.

Natalya's sympathy for the dying patient motivated her to call the nurse and to appeal to her sense of duty and care. On this occasion, the nurse gave the medication. Both Natalya and Dima are exasperated at how a fundamental moral rule about care for patients can so easily be ignored. It seems that Kyrgyzstani doctors and nurses have interpreted the market ideology, 
which informs the economic reforms in the public sector, in ways that place the responsibility of care not on them but on the patients, their clients. It is the patients who must choose whether they wish to purchase medical services. This consumerist discourse shifts the other discourses of human rights, professional ethics and basic needs to the margins. As the market discourse of choice, exchange and money becomes more ingrained in the public sector and professional services, its effects seem to have led to unsympathetic behaviour and unjust consequences.

Furthermore, as in higher education, nonmarket institutions such as medical associations, either do not exist or are too weak to cultivate professional ethics and to engage critically with market discourse. In part, the lack of effective institutions is due to the Soviet legacy of state control of professional groups and trade unions together with people's distrust of ideals of workers solidarity.

\section{Social networks}

While social gatherings and acts of intimacy are of fundamental concern, especially as we are psychologically dependent on others for care, social approval and recognition, the opportunity cost of undertaking such activities has risen since the removal of state subsidies for basic goods and services and the increase in unemployment. For lack of economic resources, poor households limit their social contacts to avoid being shamed and humiliated in public (Kuehnast and Dudwick 2002). Many interviewees are upset at how their relationships with friends and acquaintances have changed, as increasing costs have meant cutting back on social gatherings.

Tamara (a kiosk sales assistant): Before, we used to see each other more frequently at birthday parties and celebrations, but now we meet only if they celebrate an anniversary.

Interviewer: And why is that so?

Tamara: It is because living is more difficult now. Previously groceries were cheaper, everybody had a table full of food, now there are only white potatoes and bread. It is uncomfortable to visit others; they may start thinking we are visiting them too often, besides Kyrgyz people have large families.

Interviewer: Why would they think you are visiting them too often?
Tamara: It is just not right; of course we would not go there empty-handed. In the past, people would not think you were visiting them too often; everybody visited each other frequently, they would travel all the way up to Naryn [region], and sometimes even once a week. But now that happens only two to three times a year, and only for celebrations or weddings.

Tamara is upset that she and other poor individuals have to reduce their social contacts so as to avoid possible humiliating situations of arriving empty-handed. Nevertheless, poor households are committed to close family members, since concern for the family is deeply rooted. This strong sense of commitment marks the domestic sphere as an exceptional relationship, resistant to economic pressures.

\section{Real markets}

Hirschman (1982) argues that commerce and competition can act as a moralising agent. In the process of trading individuals learn to be honest and prudent so as not to damage their creditworthiness and reputation. Liberal markets appear to foster various ethical values including formal equality, autonomy and freedom, and in them individuals are encouraged to be more responsible and to pursue their own goals. Aida, a lawyer, discusses how the transition to a market economy has affected Kyrgyzstanis' capacity to pursue their own interests in more "civilised" ways.

Now we have something close to civilised business, but earlier [just after the collapse of communism] everybody was ready to cheat everyone else, even their own mothers, for the sake of profit. Now the market dictates different conditions and a reliable partner means a lot. Earlier, everybody thought only about himself and lived from day to day. Nowadays people think about the future, about their image. If you show yourself to be unreliable, then you are as good as dead - no partners, no reputation!

In contrast, most citizens under the Soviet system had very little control over their purchases in the formal economy and they were poorly motivated to work. Nevertheless, they participated in the informal or underground economy to obtain the consumer goods they wanted through giving bribes (blat), doing favours for friends and acquaintances and cheating and deceiving officials. Aida, who lived 
for much of her life under the Soviet regime, feels that people are now more honest.

However, competitive capitalistic markets can just as easily foster a culture of dishonesty and corruption and reinforce exploitative and unequal power relations in the economy. While abstract markets can in theory operate according to the liberal principles of freedom and equality, real markets are more complex, since they involve and presuppose non-market relationships that are contingent on and reflect historical, cultural and political pressures (Polanyi 2001). In Kyrgyzstan, the social embeddedness of markets reflects illiberal social processes and institutions. Many political scientists such as Collins (2002) describe how elite clans, criminal organisations and powerful political families influence the Kyrgyzstani polity and economy. Before Askar Akayev's 13-year regime was overthrown in the popular uprising in March 2005 it was widely reported in the opposition newspapers that he and his family had accumulated a massive personal fortune through shareholdings in large businesses and that major economic contracts were often awarded to his friends and clan members to shore up their political loyalty and support.

Furthermore, the tradition of Soviet practices of giving bribes and asking for "gifts" (blat) continues to affect economic relationships (Ledeneva 1998, pp. 206-214). Many Kyrgyzstanis have adapted blat to the new market conditions by demanding bribes and offering gifts to ensure that contracts are awarded. Many interviewees note that real markets are riddled with bribes and social connections. Gulzat, a housewife and formerly a nurse, describes how her brother had to give a bribe for her husband to get a job:

Market relations describe everything: if you don't give a bribe, you won't find a good job. When my husband was getting his job, my older brother gave away his colt to help him with his job. We do not regret that we gave away the horse.

Both Aida and Gulzat point to an important understanding of markets: whether real markets encourage trustworthiness or facilitate dishonesty depends on how social institutions, norms, customs and rules affect concrete markets and how individuals evaluate economic success and integrity in their particular context. Real markets are always a site of moral assessments and implicit ethical commitments.
Some writers (such as Kaneff 2002) suggest that market trading is shameful because during the Soviet period trade was condemned as spekulatsiya (profiteering), and was seen as an exploitative and unproductive form of generating wealth. In some parts of Eastern Europe and the Caucasus, the Soviet legacy of condemning and having a low regard for market trading continues to affect marketplaces, and traders are ashamed of their activities. However, amongst our interviewees there was no expression of shame about market trading, or any mention of condemning spekulatsiya. In Kyrgyzstan, shuttle-trading can sometimes be seen as exciting since traders travel to Europe, India, China or Turkey to procure designer clothes, perfumes and jewellery. Kyrgyzstan has one of the largest indoor marketplaces in central Asia located in the capital, Bishkek.

Instead we observed that shame and embarrassment are often expressed by pensioners, old women and professionals who are forced to sell produce from their garden allotments or bits of their belongings, such as books and Soviet medals, to passers-by. ${ }^{7}$ These causal sellers are located on street corners, outside their homes and on the fringes of large marketplaces and are pushed into selling bric-a-brac and foodstuffs because they cannot make ends meet on their low state salary or monthly pension. The sellers are embarrassed to have to bare their suffering and hardship so openly in public, and would prefer to have a decent state income. Their shame reflects their suffering and their inability to live well, rather than going against cultural norms about spekulatsiya.

Nevertheless, the market system can evoke negative emotions such as anger and shame, in other ways. The market system caters for the social classes who have the wealth and income to exercise consumer choice, but it ignores poorer groups, who have insufficient means to make their wants count. In capitalist societies, an uneven class structure often affects real markets. Asel, the non-governmental organisation director, describes her frustration with a market system that cares little for vulnerable and poor groups:

[During the Soviet times], there was a lack of groceries and industrial goods, so in order to buy footwear we had to find friends - this was normal practice. Or on the eve of holidays, special stores would be closed to serve the cream 
of the society. But, now I can purchase those items in any kiosk. I give my total support to the system in this respect, though it is another matter when people do not have the money to buy goods or to support their children. We have a new puzzle: in the past, we had the money, but there were no goods to buy, and now we have the goods, but no money to buy them. We have gone from one extreme to another.

In criticising the market system Asel is not being nostalgic about the Soviet days since she recognises that the old regime was corrupt. Rather she rightly argues that markets are affected by economic and social inequalities, causing disappointment and hurt. The transition to a market economy has left many vulnerable, poor and needy groups without the capabilities to achieve human well-being.

\section{Concluding remarks}

The article discussed three competing approaches to the post-Soviet moral economy. One major weakness of the economic market approach is that it views human beings as largely driven by selfish motives. In fact we are vulnerable and needy beings who must care for and be cared for by others outside the marketplace. While the socially embedded approach acknowledges that economic behaviour involves rules, rights and norms, we have shown how moral emotions, commitments and character matter in making moral judgements on how to live. The moral sentiments approach offers a better understanding of human agents as reflexive beings who deliberate on ways to pursue their ultimate concerns, commitments and life projects. In making moral assessments of their local contexts, moral sentiments inform and motivate individuals to balance internal values (integrity, justice, worthiness, professionalism and equality) with external goals (income, power, status and targets). Moral sentiments are relational, involving our dependence on and care for others and cannot be thought of as subjective whims and irrational preferences, or as ideological false consciousness, though we can make mistakes about their causes, consequences and significance.

In our study on Kyrgyzstan, we saw how material interests and economic structures (including opportunity costs, competition and inequalities) affected the public sector, social networks and real markets, creating tensions between internal and external values and undermining social dignity. In particular, we showed how markets and social inequalities affected moral sentiments, ethical valuations and commitments. Among these, for instance, are the market's civilising effects, the shame arising from poverty and economic concerns that make it necessary to sideline care and responsibilities.

We have suggested that poor individuals have good reasons to be frustrated and angry and to fear for their well-being. They lack real human agency and capabilities. Inequalities and poverty have deprived Kyrgyzstanis of valuable activities and goods, such as decent employment, quality education, good health, caring relationships, social worth and respect. Lacking human capabilities and operating in harsh economic conditions, since independence most Kyrgyzstanis have had to sacrifice their professional and work commitments to make ends meet, to restrict their participation in social networks and to endure shame in scratching a living. The popular revolt in March 2005 showed both their frustration and anger at the present social system, and their desire and hope for something better.

We hope that this article will motivate others to join in the debate on how everyday normativity interrelates with post-Soviet economies, as a contribution to forging a normative social science.

\section{Notes}

1. The research project was funded by the American University, Central Asia Research Grant Committee and the University of Kent Social Science
Faculty Grant Committee. We are grateful to Chris Pickvance, Sarah Amsler, Vanessa Ruget, Tatiana Yarkova and Iain Wilkinson for their constructive comments and support. Our thanks to Mehrigiul Ablezova, Emil Juraev and Asyl Bakanova for their contribution to the study. Finally, we would like to express our gratitude to the 
interviewees for their time, guidance and patience. The usual disclaimers apply.

2. A moral economy is defined as an object and a kind of inquiry that focus on how economic activities of all kinds are influenced and structured by moral dispositions, values and norms, and how these in turn are reinforced, shaped, compromised or overridden by economic pressures (Sayer 2004, p. 2).
3. Note that moral emotions play a role in this approach. While the three approaches to the moral economy are distinct in their core ideas, they do overlap.

4. Smith points out it is not thanks to the benevolence of baker, brewer and butcher that we get our dinner, but from our appeal to their self-interest (1976 [1774], pp. 118-119]).

5. MacIntyre (1985, p. 191, p. 194) also notes that while institutions and external goods, such as power, income and status, help to sustain social practices, in the absence of moral emotions and virtues social practices cannot resist the corrupting power of external demands.

6. The names of the participants have been changed to ensure anonymity.

7. We are grateful to Rachel Marcus for bringing this to our attention.

\section{References}

Anderson, J. 1999. Kyrgyzstan: Central Asia's island of democracy? London: Routledge.

Archer, M. 2000. Being human: the problem of agency. Cambridge: Cambridge University Press.

Archer, M. 2003. Structure, agency and the internal conversation.

Cambridge: Cambridge University Press.

AtTwood, L. 1997. "She was asking for it: rape and domestic violence against women", In: Buckley, M., ed. Post-Soviet women: from the Baltic to Central Asia. Cambridge: Cambridge University Press.

Bоотн, W. 1994. "On the idea of the moral economy", American Political Science Review, 88 (3), 653 667.

Burawoy, M. And Verdery, K., eds., 1999. Uncertain transition: ethnographies of change in the postsocialist world. Lanham: Rowman and Littlefield.

Collins, K. 2002. "Clans, pacts, and politics in central Asia", Journal of Democracy, 13 (3), 137-152.

Durkheim, E. 1957. Professional ethics and civic morals. London: Routledge \& Kegan Paul.
Etzioni, A. 1988. The moral dimension: toward a new economics. New York: The Free Press.

Fevre, R. 2003. The new sociology of economic behaviour. London: Sage Publications.

Folbre, N. 1994. Who pays for the kids? Gender and the structures of constraints. London: Routledge.

Green, D. and Bauer, A. 1998. "The costs of transition in central Asia", Journal of Asian Economics, 9 (2), 345-364.

Granovetter, M. 1985. "Economic action and social structure: the problem of embeddedness", American Journal of Sociology, 91 (3), 481-510.

Griswold, C. 1999. Adam Smith and the virtues of enlightenment. Cambridge: Cambridge University Press.

Groenhout, R. 2004. Connected lives: human nature and an ethics of care. Lanham: Rowman and Littlefield.

Hann, C. 2003. "Introduction: decollectivization and the moral economy", In: Hann, C. and the Property Relations Group, eds. The post socialist agrarian question: property relations and the rural condition. New Brunswick, NJ: Transaction Publishers.

Hirschman, A. O. 1982. "Rival interpretations of the market society: civilizing, destructive, or feeble?", Journal of Economic Literature, 20 (4), 1463-1484.

Holton, R. 1992. Economy and society. Routledge, London.

INTERNATIONAL SOCIAL SCIENCE JOURNAL 2005. Moralising capitalism. 57 (185).

KANEFF, D. 2002. "The shame and pride of market activity", In:

Mandel, R. and Humphrey, C., eds. Markets and moralities:

ethnographies of post-socialism.

Oxford: Berg.

KeAt, R. 2000. Cultural goods and the limits of the market. Basingstoke Macmillan.

Kopstein, J. 2001. "Globalisation in one country: East Germany between moral economy and political economy", In: Candland, C. and Sil, R., eds. The politics of labour in a global age: continuity and change in late-industrialising and post-socialist economies. Oxford Scholarship Online: Oxford University Press.

Kuehnast, K. And Dudwick, N. 2002. "Better a hundred friends than a hundred rubles? Social networks 
in transition - the Kyrgyz

Republic", World Bank Economists Forum, 2, 51-88.

Ledeneva, A. (1998). Russia's economy of favours: blat, networking and informal exchange. Cambridge: Cambridge University Press.

LiU, M. 2003. "Detours from utopia on the Silk Road: ethical dilemmas of neoliberal triumphalism", Central Eurasian Studies Review, 2 (2), 2-10.

Macintyre, A. 1985. After virtue: $a$ study in moral theory. London: Duckworth.

Mandel, R. And Humphrey, C., eds, 2002. Markets and moralities: ethnographies of post socialism. Oxford: Berg.

Mason, A. 1996. "MacIntyre on modernity and how it has marginalized the virtues", In: Crisp, R., ed. How should one live? Essays on the virtues. Oxford: Oxford University Press.

NazPary, J. 2002. Post-Soviet chaos: violence and dispossession in Kazakhstan. London: Pluto.

NeE, V. 1989. "The theory of market transition: from redistribution to markets in state socialism", American Sociological Review, 54 (5), 663-681.

Nussbaum, M. 2000. “Women's capabilities and social justice", Journal of Human Development, 1 (2), 219-247.

Nussbaum, M. 2001. Upheaval of thought: the intelligence of emotions. Cambridge: Cambridge University Press.

Nussbaum, M. 2004. Hiding from humanity: disgust, shame and the law. Princeton, NJ: Princeton University Press.

O'NeIll, J. 1998. The market: ethics, knowledge and politics. London: Routledge.

OAKley, J. And Cocking, D. 2001. Virtue ethics and professional roles. Cambridge: Cambridge University Press.
OfFE, C. 1984. Contradictions of the welfare state. London: Hutchinson.

OfFe, C. 1996. "The morality of restitution: reflections on some normative questions raised by the transition to a private economy" (with Frank Bonker). In: Offe, C., Varieties of transition: the East European and East German experience. Cambridge: Polity Press.

Oliver de Sardan, J. P. 1999. “A moral economy of corruption in Africa?" Journal of Modern African Studies, 37 (1), 25-52.

Pharo, P. 2005. "The ethics of competition", International Social Science Journal, 57 (185), 445-455.

Polanyi, K. 2001. "The economy as instituted process", In: Granovetter, M. and Swedberg, R., eds. The sociology of economic life. 2nd edn. Boulder, CO: Westview Press.

PozNANSKI, K. 2000. "The morals of transition: decline of public interest and runaway reforms in Eastern Europe", In: Antohi, S. and Tismaneanu, V., eds. Between past and future: the revolutions of 1989 and their aftermath. Budapest: Central European University Press.

SAYER, A. 1995. Radical political economy: a critique. Oxford: Blackwell.

SAYER, A. 2003. "Restoring the moral dimension: acknowledging lay normativity", Department of Sociology. Lancaster: Lancaster University.

SAYER, A. 2004. "Moral economy", Department of Sociology.

Lancaster: Lancaster University.

SAYer, A. 2005. The moral significance of class. Cambridge: Cambridge University Press.

SEN, A. 1999. Development as freedom. Oxford: Oxford University Press.

Simmel, G. 1955. Conflict and the web of group-affiliation. New York: Free Press.
Smith, A. 1974 [1776]. The wealth of nations. Books I - III.

Harmondsworth: Penguin Classics.

Smith, A. 1976 [1790]. The theory of moral sentiments. Indianapolis: Liberty Fund.

Szelenyi, I. And Kostello, E. 1996. "The market transition debate: toward a synthesis?" American Journal of Sociology, 101 (4), $1082-$ 1096.

The Times Higher Education Supplement. 2006. "Passing exams is a real gift", 17 February, p. 13.

Thompson, E. P. 1971. "The moral economy of the English crowd in the eighteenth century", Past and Present, 50 (1), 76-136.

Tronto, J. 1993. Moral boundaries: a political argument for an ethic of care. New York: Routledge.

UNDP 2002. The macroeconomics of poverty: a case study of the Kyrgyz Republic. Available online at http:// www.undp.org/poverty/docs/sppr/ KYRGYZ\%20Report.doc [Accessed 28 February 2008].

VAn Staveren, I. 2001. The values of economics: an Aristotelian perspective. London: Routledge.

Veblen, T. 1918. The theory of the leisure class: an economic study of institutions. New York: Book of the Month Club.

Verdery, K. 1996. What was socialism, and what comes next? Princeton, NJ: Princeton University Press.

WALzer, M. 1983. Spheres of justice. New York: Basic Books.

Williamson, O. E. 1975. Markets and hierarchies: analysis and antitrust implications: a study of in the economics of internal organizations. New York: Free Press.

World Resource Institute 2006. "Country profile - Kyrgyzstan". Available online at http:// earthtrends.wri.org/text/economicsbusiness/country-profile-101.html [Accessed 28 February 2008]. 